\title{
Preparation of Carrier-free Yttrium-88 from Strontium Target by Solvent Extraction ${ }^{\dagger}$
}

\author{
Nagao IkedA, Kan Kimura, Riki SeKI and Hideharu Fujimoto \\ Department of Chemistry, Tokyo Kyoiku University \\ Otsuka, Tokyo
}

Received December 2, 1975

\section{Introduction}

Preparation of a radioactive yttrium tracer is of much interest in relation to rare earth chemistry. Usually, ${ }^{90} \mathrm{Y}$ (half-life: $64.0 \mathrm{~h})$ separated from ${ }^{90} \mathrm{Sr}$, or ${ }^{91} \mathrm{Y}(58.8 \mathrm{~d})$ processed from fission products has been used for tracer studies. These nuclides are, however, almost pure $\beta$-emitters which need rather tedious $\beta$-counting. In this point of view, ${ }^{88} \mathrm{Y}$ seems quite favorable, because it decays mainly by electron capture with $\gamma$ transitions and it has a suitable half-life (108.1 d) for tracer works.

For the production of ${ }^{88} \mathrm{Y}$, several ways are possible. Among them, ${ }^{89} \mathrm{Y}(n, 2 n)^{88} \mathrm{Y}$ or ${ }^{89} \mathrm{Y}(\gamma, n)^{88} \mathrm{Y}$ reaction produces ${ }^{88} \mathrm{Y}$ with the isotopic carrier ${ }^{89} \mathrm{Y}$. Physicochemical works sometimes demand that the tracer to be used should have as high a specific activity as possible. To fulfil the requirement, production of carrier-free ${ }^{88} \mathbf{Y}$ is desirable. It seems to be one of the most suitable ways to separate carrier-free ${ }^{88} \mathrm{Y}$ from deuteronor proton-bombarded strontium target. As for the proton bombardment on strontium, Sachdev, Porile and Yaffe $^{1)}$ measured the cross section of the ${ }^{88} \mathrm{Sr}(p, n){ }^{88} \mathrm{Y}$ reaction, showing the maximum value of $1000 \mathrm{mb}$ at $E_{p}=13 \mathrm{MeV}$.

As to the mutual separation of yttrium and strontium, separation of carrier-free ${ }^{90} \mathrm{Y}$ from its parent ${ }^{90} \mathrm{Sr}$ has been well-studied $^{2)}$. The methods are based on surface adsorption, coprecipitation, ion-exchange chromatography, paper chromatography, solvent extraction, etc.

In the case of isolation of ${ }^{88} \mathrm{Y}$ from a strontium target, the situation is rather complicated because of the presence of macroamounts of strontium in the target solution, and of hard $\gamma$-radiations emitted by ${ }^{88} Y$ and some radioactive impurities. Solvent extraction seems the most convenient for isolation of ${ }^{88} Y$, because the salting-out effect of strontium salt is expected and the extraction procedure is generally rapid and simple. This paper deals with the preparation of carrier-f ree ${ }^{88} Y$ from proton-bombarded strontium oxide by solvent extraction with bis (2-ethylhexyl) phosphoric acid (HDEHP) in toluene.

\section{Experimental}

\section{$2 \cdot 1$ Reagents}

HDEHP (supplied from Tokyo Kasei Kogyo Co., Ltd.) and other reagents were of the reagent grade and used without any further purification.

\subsection{Target and proton bombardment}

As the available proton beam was of 50 $\mathrm{MeV}$, a thick target arrangement was adopted. In the preliminary experiments, 1, 2, and $3 \mathrm{~mm}$-thick strontium oxide (powder) and $3 \mathrm{~mm}$-thick strontium borate (pellet)

†溶媒抽出法によるストロンチウムターゲットから の無担体イットリウム-88の調製。池田長生, 木 村 幹, 関 李紀, 藤本英治: 東京教育大学理学部 (東京都文京区大塚) 
targets were bombarded. Both the amount of ${ }^{88} \mathrm{Y}$ induced and ${ }^{88} \mathrm{Y} /{ }^{85} \mathrm{Sr}$ ratio were found to increase with increasing total thickness of the target, corresponding to the excitation function reported by Sachdev, et al. ${ }^{1}$ There was no trouble with heat removal from thick targets during irradiation. The use of strontium oxide simplified the target preparation and post-irradiation chemical treatments as compared with the use of borate. Therefore strontium oxide was used as the target.

Strontium oxide was charged in a $25 \mathrm{~mm}$ (height) $\times 30 \mathrm{~mm}$ (width) $\times 5 \mathrm{~mm}$ (thickness) or a $25 \times 30 \times 12 \mathrm{~mm}$ cell made of $0.2 \mathrm{~mm}$-thick aluminum foil and the mouth of each cell was closed at $20 \mathrm{~mm}$ height. The cells were set in a target holder of 70-inch synchrocyclotron at Institute for Nuclear Study, Tokyo University, and bombarded in 50 $\mathrm{MeV}$ proton beam ( $0.85 \mu \mathrm{A}$ on the average) for $1.5 \mathrm{~h}$.

The target was stored for sufficient time to diminish the activity of ${ }^{87} \mathrm{Y}(80 \mathrm{~h})$ which decays to ${ }^{87 m} \mathrm{Sr}(2.83 \mathrm{~h})$, and then subjected to separation of ${ }^{88} \mathrm{Y}$.

\subsection{Chemical procedure}

The procedure for separation of ${ }^{88} \mathrm{Y}$ from the irradiated target was developed being based on the solvent extraction data ${ }^{3)}$. The bombarded target was dissolved in a little excess of $6 \mathrm{~N} \mathrm{HCl}$. The solution was evaporated to near dryness. The residue was dissolved in $100 \mathrm{~m} l$ of $0.1 \mathrm{~N} \mathrm{HCl}$. The solution was shaken with $10 \mathrm{ml}$ of $50 \%$ HDEHP (toluene solution) to extract ${ }^{88} \mathrm{Y}$. The extraction was repeated twice. The organic phases were combined and washed twice with each $20 \mathrm{ml}$ of $0.1 \mathrm{~N} \mathrm{HCl}$. The organic phase was then shaken with $5 \mathrm{~m} l$ of $10 \mathrm{~N}$ $\mathrm{HCl}$ to extract ${ }^{88} \mathrm{Y}$ in aqueous phase. The back-extraction was repeated 4 times. The combined aqueous phase was washed twice with each $20 \mathrm{~m} l$ of toluene.

\section{Results and discussion}

The $\gamma$ rays from the irradiated target were measured by a $\mathrm{Ge}(\mathrm{Li})$;detector-4096 channel pulse height analyzer counting system. A $\gamma$-ray spectrum of irradiated target together with aluminum backing, after cooling for $16 \mathrm{~d}$, is shown in Fig. 1.

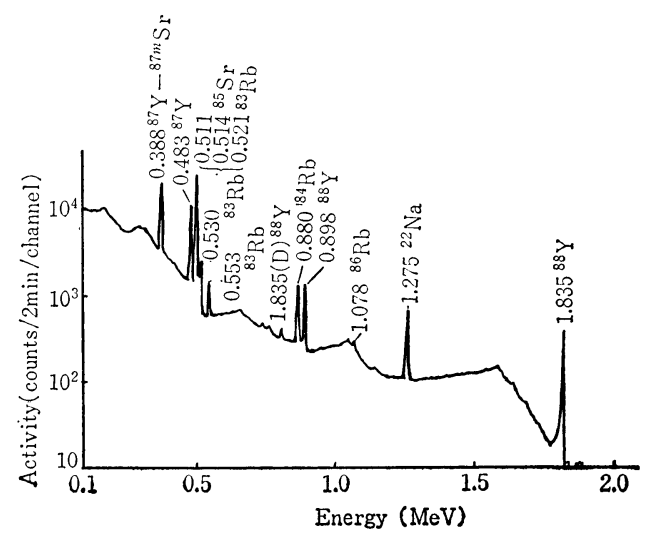

Fig. 1 The $\gamma$-ray spectrum of the irradiated strontium target.

The irradiated target was found to contain ${ }^{87} \mathrm{Y}(80 \mathrm{~h}),{ }^{87 m} \mathrm{Sr}(2.83 \mathrm{~h}),{ }^{85} \mathrm{Sr}(64.0 \mathrm{~d})$, ${ }^{83} \mathrm{Rb}(83 \mathrm{~d}),{ }^{84} \mathrm{Rb}(33.0 \mathrm{~d})$ and ${ }^{86} \mathrm{Rb}(18.66 \mathrm{~d})$ in addition to ${ }^{88} \mathrm{Y}$ (108.1d). The $1.275 \mathrm{MeV}$ photopeak was assigned to ${ }^{22} \mathrm{Na}$ produced probably by ${ }^{27} \mathrm{Al}(p, 3 p 3 n)^{22} \mathrm{Na}$ reaction in the aluminum backing. At cooling time of $5 \mathrm{~d}$, photopeaks due to ${ }^{86} \mathrm{Y}(14.6 \mathrm{~h}),{ }^{87 m} \mathrm{Y}(14 \mathrm{~h})$ and ${ }^{83} \mathrm{Sr}(32.4 \mathrm{~h})$ were also observed.

To check the separation procedures written in $2 \cdot 3$, the activity of an aliquot of each aqueous and organic phase at each separation step was measured. It was revealed that the distribution ratios for yttrium and strontium differ by a factor of approximately $10^{6}$, and carrier-free ${ }^{88} Y$ was obtained in very high radionuclidic purity. The $\gamma$-ray spectrum of the final ${ }^{88} \mathrm{Y}$ product is

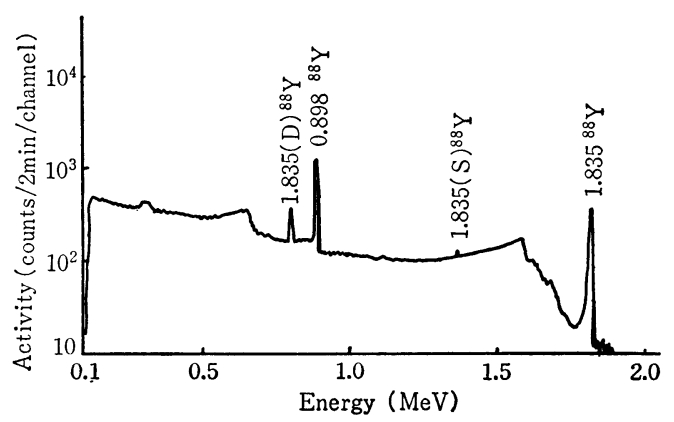

Fig. 2 The $\gamma$-ray spectrum of the ${ }^{88} \mathrm{Y}$ pruduct. 
shown in Fig. 2. The radionuclidic purity of the product ${ }^{88} Y$ was examined also radiochemically: An aliquot was taken from the final ${ }^{88} Y$ product solution, and ${ }^{88} Y$ in the aliquot was completely removed by extraction. Then ${ }^{85} \mathrm{Sr}$ retained in the aliquot was determined $\gamma$-ray spectrometrically by accumulating $r$ pulses for $5.5 \mathrm{~h}$. This examination proved that ${ }^{85} \mathrm{Sr}$ activity in the final ${ }^{88} \mathrm{Y}$ product was one thousandth as low as ${ }^{88} Y$ activity at about 2 months after the bombardment. It was also revealed that more than $99 \%$ of ${ }^{88} \mathrm{Y}$ was recovered in the final product solution.

By the procedures shown in $2 \cdot 3$, carrierfree ${ }^{88} \mathrm{Y}$ can be directly obtained in high radionuclidic purity, and it takes only $1 \mathrm{~h}$ or less for the separation process. It is thus concluded that a very simple extraction-washing cycle offers a method for a rapid preparation of carrier-free yttrium from the irradiated strontium target.

The authors wish to thank Professor Y. Ishizaki and the cyclotron crew of Institute for Nuclear Study, Tokyo University, for proton bombardments. Part of the expenses of this work was covered by a grant from the Ministry of Education of Japan, to which the authors' thanks are due.

\section{References}

1) D.R. Sachdev, N.T. Porile, L. Yaffe: Can. J. Chem., 45, 1149 (1967)

2) For instance, N. Ikeda, J. Akaishi, Y. Ono: Radioisotopes, 8, 233 (1959); D.F. Peppard, G.W. Mason, S.W. Moline: J. Inorg. Nucl. Chem., 5, 141 (1957); S. Misumi, T. Taketatsu: J. Chem. Soc. Japan, Pure Chem. Sec., 80, 1071 (1959)

3) K. Kimura: Bull. Chem. Soc. Japan, 33, 1038 (1960); 34, 63 (1961) 